\title{
Stability and Emission Characteristics of Diesel-Ethanol-Coconut Methyl Ester Blends for the Diesel Engines
}

Tanti Ardiyati ${ }^{1}$

Nathaniel P. Dugos *,1

Susan A. Roces ${ }^{1}$

Masaaki Suzuki ${ }^{2}$

Kusnanto ${ }^{3}$

${ }^{1}$ Chemical Engineering Department, De La Salle University, 2401 Taft Ave, Manila 0922, Philippines

2 Chemical Engineering Department, Tokyo Institute of Technology, 4259 Nagatsutacho, Midori Ward, Yokohama, Kanagawa Prefecture 226-0026, Japan

${ }^{3}$ Physics Engineering Department, Gadjah Mada University, Jl. Grafika No.2, Yogyakarta 55281, Indonesia

*e-mail : nathaniel.dugos@dlsu.edu.ph

The stability and emission characteristics of diesel-ethanol-coconut methyl ester (CME) blends were studied to determine the most suitable fuel blends to be applied in diesel engines. This is done in order to assess the potential of the blends as a substitute for commercially available diesel fuel used in diesel engine. The stability results of the blends using $100 \%$ and $99.5 \%$ ethanol purity showed that the fuel blends containing ethanol up to $10 \%$ and $\mathrm{CME}$ of $5 \%$ and greater exhibited high mutual solubility at any temperature range and were resistant to microbial growths after 3 months storage. Engine operations at low speed especially at idle-no load and using a bigger size engine lead to a minimum ignition delay and result in lower fuel consumption rate. The emission test results with the newblended fuels showed a reduction in $\mathrm{CO}_{2}$ and increasing percentage by volume of $\mathrm{CO}$ compared to commercially available diesel. The blends could deliver an efficient combustion and could run efficiently since production of the $\mathrm{CO}_{2}$ gases is higher than that of $\mathrm{CO}$. The blends of $80 \%$ diesel, $5 \%$ ethanol, $10 \%$ CME; and $80 \%$ diesel, $10 \%$ ethanol, $10 \%$ CME could reduce the smoke opacity compared to commercially available diesel.

Keywords: Coconut methyl ester, Diesel, Ethanol

\section{INTRODUCTION}

Exhaust emissions from public and private vehicles, and dependence on fossil fuels have long been a matter of important concern. To answer this problem, alternative fuel from renewable bio-based resource is needed. Biodiesel and diesohol (diesel-ethanol blends) are kind of biofuels that can be used in diesel engines as a substitute for commercially available diesel fuel.

Diesel-ethanol blends have been studied since long time ago in order to 
2 Stability and Emission Characteristics of Diesel-Ethanol-Coconut Methyl Ester Blends for the Diesel Engines

reduce the dependence on fossil fuels and exhaust emission of diesel engine. However, a serious obstacle in using ethanol-diesel fuel blends may occur. Ethanol which has a different chemical structure and characteristics with that of diesel fuel, makes these two liquids immiscible at low temperatures (Kwanchareon et al., 2007; De Caro et al., 2001). Aside from that, diesel mostly consists of non-polar molecule because of the presence of long chain hydrocarbons while ethanol contains the hydroxyl $(\mathrm{OH}-)$ group, which is polar, and the blending of polar and non-polar molecule will result in fuel instability.

To prevent the phase separation of diesel-ethanol lends at low temperature, additives may be added. An emulsifier as additive acts to prevent the immiscibility of the fuel blends and the emulsification process usually requires heating and blending.

Biodiesel is suitable to be an emulsifier since it contains both lipophilic and hydrophilic part that can increase the affinity of ethanol-diesel blend and thus will result to emulsion stability (Cheenkachorn et al., 2006). Coconut oil biodiesel in which the chemical name is coconut methyl ester (CME), is the proposed emulsifier for the ethanol-diesel blend. CME has the capability to emulsify the blend, increase the affinity of the component of the blend and its use will not result to engine compatibility problem.

Biodiesel as an emulsifier comes from many varieties of edible and non-edible oils such as palm oil biodiesel (Kwanchareon et al., 2007), sunflower methyl ester (Rahimi et al., 2006), soybean biodiesel (Kim and Choi, 2010 and Pang et al., 2006), rice bran oil biodiesel (Subbaiah et al., 2010; Singh et al., 2007 and Venkanna et al., 2009) and these have been proven to reduce $\mathrm{CO}, \mathrm{THC}$, smoke emission, and particulate matter and have similar characteristics to the commercially available diesel fuel.

The blends of soybean biodiesel-dieselethanol in CRDI 4 cylinder diesel engine showed similar engine performance to that of diesel fuel (Kim and Choi, 2010). The lower calorific value of the blends caused the higher fuel consumption. Though the blend could decrease $\mathrm{CO}$, THC, smoke emissions and total number of particles emitted from CRDI diesel engine, the amount of NOx increased.

A research which was conducted in wagon type, 4-cylinder diesel engine using the blends with proportion of $78 \%$ diesel, $20 \%$ biodiesel and $2 \%$ ethanol could make the BSFC and cold start time comparable to diesel (Randazzo and Sodré, 2011).

The blend of rice bran oil biodiesel up to $20 \%$ in diesel-biodiesel-ethanol blends have been studied and concluded that this blend can be applied on direct injection diesel engine without any modification. Brake specific fuel consumption, smoke opacity, $\mathrm{CO}, \mathrm{HC}$ and $\mathrm{NOx}$ were reported to have value close to the neat diesel fuel (Venkanna et al., 2009).

The proportion of diesel, soybean methyl ester and ethanol of 70:25:5 in single cylinder, 4 stroke, direct injection, diesel engine could decrease BSFC, smoke and $\mathrm{CO}$ values of the blends (Qi et al., 2011). These values were considered lower compared to diesel. NOx and HC were considered higher than diesel. 
The objective of this study is to examine the stability and emission characteristics of the diesel-ethanolcoconut methyl ester (CME) blends as a substitute for conventional diesel fuel used in diesel engine.

\section{MATERIALS AND METHODS}

The experiment was conducted by mixing diesel, ethanol and CME at different proportions using the adjusted concentration of ethanol to produce the blends. The ethanol concentrations were varied at $99.5 \%$ and $100 \%$ by volume to study the effect of the presence of water in the phase stability of the blends.

The emulsification processes of the blends were conducted at room temperature using a well-insulated blender by setting its speed at $13,000 \mathrm{rpm}$ for 5 minutes to keep the blends in its homogenous state. The same procedures were carried out to all of the nine fuel blends. The emulsions were placed in reagent bottles and then were stored in a refrigerator and water bath for seven days at $10^{\circ} \mathrm{C}, 25^{\circ} \mathrm{C}, 30^{\circ} \mathrm{C}$ and $40^{\circ} \mathrm{C}$ to observe the physical stabilities. After seven days storage, all stable samples were kept further at room temperature for three months to observe the long-term stability.

The indications of a stable blend were no formation of sediment layer and agglomeration of liquids droplets; and presence of possible microbial growth. The identification of microbial growth was done visually at ambient temperature by identifying the color degradation, the appearance of mist, and the formation of microbial layer in the blends' surface
(Alleman and McCormick, 2006).

The fuel blends that had the most stable characteristics were then subjected to engine performance and emission testing. In the engine testing, the blends were used as fuel in the Yanmar L100-AE diesel engine. This is a commercial single cylinder, vertical-4 cycle, 0.406 L displacement, 19.3:1 compression ratio, direct injection diesel engine. Emission testing involved the measurement of carbon monoxide (CO), carbon dioxide $\left(\mathrm{CO}_{2}\right)$, unused oxygen $\left(\mathrm{O}_{2}\right)$, unburned hydrocarbon $(\mathrm{HC})$, nitrogen monoxide (NO) which present in the exhaust gas and these were measured using a Delta 1600-L gas analyzer while smoke opacity was measured with AVL DiSmoke 4000.

\section{RESULT AND DISCUSSIONS}

\section{Effect of Ethanol Concentration and Temperature on Phase Stability of The Blends}

The physical appearances of the blends were classified into three categories i.e.:

(1) Clear liquid one phase. In this condition, the blends appear as clear, single-phase liquid with no crystals or particles within.

(2) Clear liquid two phases. Two-phase liquid is observed in the blends for this condition. The blend has layers which are clear with no crystal or particles within.

(3) Turbid two phases. It is a two-phase liquid system. The blends appear to have layers, which is clear on the top layer and turbid on the rest. 
4 Stability and Emission Characteristics of Diesel-Ethanol-Coconut Methyl Ester Blends for the Diesel Engines

The stability test result of the dieselethanol-CME blends with $99.5 \%$ ethanol purity exhibited two behaviors. Some were miscible which appeared as one-phase clear liquid at temperatures $25^{\circ} \mathrm{C}$ and higher; and the others were immiscible which appeared as two-phase clear liquid for the blends containing 2\% CME and lower which were stored at $25^{\circ} \mathrm{C}$ and $30^{\circ} \mathrm{C}$ and two-phase turbid for the blends containing 5\% CME and lower at storage temperature of $10^{\circ} \mathrm{C}$. Long-term stability result showed that all the blends remained stable with no microbial growth detected. All stable samples are summarized in Table 1.

A homogenous solution of the blends could be obtained at $10^{\circ} \mathrm{C}$ when the $\mathrm{CME}$ proportion is 5\% and higher and 100\% ethanol purity is used to produce the blend. The absence of water in the blends exhibited high mutual miscibility at any temperature range and any proportions of the blends. The homogeneity and stability of the blends remained after the longterm stability period and no observable microbial growth appeared. All of the stable samples are summarized in Table 2.

$\mathrm{CME}$ enhanced the affinity of the diesel-ethanol blends since its long hydrocarbon tail (non-polar) will attach to ethanol molecule and its $\mathrm{Me}-\mathrm{OH}$ head (polar) will attach to the diesel molecule thus making the blends stable. This mechanism maintains the reaction in a thermodynamically stable state at certain proportion and other physical parameters (Fernando and Hanna, 2004).

Our stability results were not much different with the research using palm oil biodiesel conducted by Kwanchareon et al. (2007) and Cheenkachorn et al. (2006). The blends of palm oil biodiesel, ethanol and diesel using ethanol purity of $99.5 \%$ were immiscible at any ratio at $10^{\circ} \mathrm{C}$ and below, while at $20^{\circ} \mathrm{C}$ only the blends containing $30-70 \%$ ethanol were immiscible. At $30^{\circ}$ and $40^{\circ} \mathrm{C}$ all of the blends were miscible at

Table 1. Stability Results of The Blends Using 99.5\% Ethanol Purity

\begin{tabular}{|c|c|c|c|c|c|c|c|c|c|c|c|}
\hline \multirow{2}{*}{$\begin{array}{c}\text { Sample } \\
\text { Code }\end{array}$} & \multicolumn{3}{|c|}{ Sample } & \multicolumn{2}{|c|}{$10^{\circ} \mathrm{C}$} & \multicolumn{2}{|c|}{$25^{\circ} \mathrm{C}$} & \multicolumn{2}{|c|}{$30^{\circ} \mathrm{C}$} & \multicolumn{2}{|c|}{$40^{\circ} \mathrm{C}$} \\
\hline & $\% \mathrm{D}$ & $\%$ B & $\% \mathrm{E}$ & Appearance & Stability & Appearance & Stability & Appearance & Stability & Appearance & Stability \\
\hline B2 & 88 & 2 & 10 & $\mathrm{~T}_{2}$ & $U$ & $C_{1}$ & $S$ & $C_{1}$ & $S$ & $C_{1}$ & $S$ \\
\hline B3 & 90 & 5 & 5 & $C_{1}$ & S & $C_{1}$ & $S$ & $C_{1}$ & S & $C_{1}$ & $\mathrm{~S}$ \\
\hline B4 & 83 & 2 & 15 & $\mathrm{~T}_{2}$ & U & $\mathrm{L}_{2}$ & U & $\mathrm{L}_{2}$ & U & $C_{1}$ & $S$ \\
\hline B5 & 85 & 10 & 5 & $C_{1}$ & $S$ & $C_{1}$ & $S$ & $C_{1}$ & $S$ & $C_{1}$ & $S$ \\
\hline $\mathrm{B} 6$ & 85 & 5 & 10 & $\mathrm{~L}_{2}$ & U & $C_{1}$ & $S$ & $C_{1}$ & $\mathrm{~S}$ & $C_{1}$ & $\mathrm{~S}$ \\
\hline B7 & 80 & 15 & 5 & $C_{1}$ & $\mathrm{~S}$ & $C_{1}$ & $\mathrm{~S}$ & $C_{1}$ & $S$ & $C_{1}$ & $S$ \\
\hline B8 & 80 & 5 & 15 & $\mathrm{~L}_{2}$ & $U$ & $C_{1}$ & $\mathrm{~S}$ & $C_{1}$ & $S$ & $C_{1}$ & $\mathrm{~S}$ \\
\hline B9 & 80 & 10 & 10 & $C_{1}$ & $S$ & $C_{1}$ & S & $C_{1}$ & S & $C_{1}$ & $S$ \\
\hline
\end{tabular}

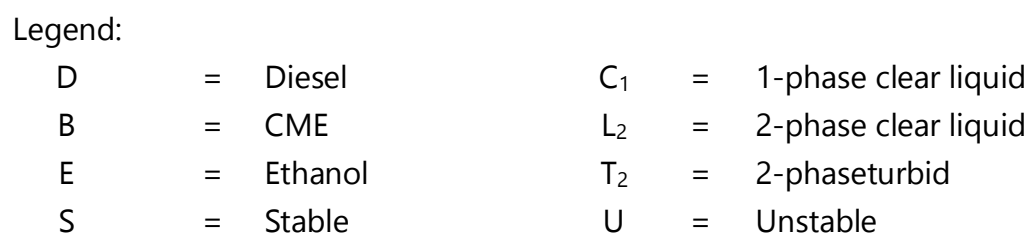


Table 2. Stability Results of The Blends Using 100\% Ethanol Purity

\begin{tabular}{|c|c|c|c|c|c|c|c|c|c|c|c|}
\hline \multirow{2}{*}{$\begin{array}{c}\text { Sample } \\
\text { Code }\end{array}$} & \multicolumn{3}{|c|}{ Sample } & \multicolumn{2}{c|}{$\mathbf{1 0}^{\circ} \mathbf{C}$} & \multicolumn{2}{c|}{$\mathbf{2 5}^{\circ} \mathbf{C}$} & \multicolumn{2}{|c|}{$\mathbf{3 0}^{\circ} \mathbf{C}$} & \multicolumn{2}{|c|}{$\mathbf{4 0}^{\circ} \mathbf{C}$} \\
\hline & \%D & \%B & \%E & Appearance & Stability & Appearance & Stability & Appearance & Stability & Appearance & Stability \\
\hline $\mathrm{A} 1$ & 100 & 0 & 0 & $\mathrm{C}_{1}$ & $\mathrm{~S}$ & $\mathrm{C}_{1}$ & $\mathrm{~S}$ & $\mathrm{C}_{1}$ & $\mathrm{~S}$ & $\mathrm{C}_{1}$ & $\mathrm{~S}$ \\
\hline $\mathrm{A} 2$ & 88 & 2 & 10 & $\mathrm{~L}_{2}$ & $\mathrm{U}$ & $\mathrm{C}_{1}$ & $\mathrm{~S}$ & $\mathrm{C}_{1}$ & $\mathrm{~S}$ & $\mathrm{C}_{1}$ & $\mathrm{~S}$ \\
\hline $\mathrm{A} 3$ & 90 & 5 & 5 & $\mathrm{C}_{1}$ & $\mathrm{~S}$ & $\mathrm{C}_{1}$ & $\mathrm{~S}$ & $\mathrm{C}_{1}$ & $\mathrm{~S}$ & $\mathrm{C}_{1}$ & $\mathrm{~S}$ \\
\hline $\mathrm{A} 4$ & 83 & 2 & 15 & $\mathrm{~L}_{2}$ & $\mathrm{U}$ & $\mathrm{C}_{1}$ & $\mathrm{~S}$ & $\mathrm{C}_{1}$ & $\mathrm{~S}$ & $\mathrm{C}_{1}$ & $\mathrm{~S}$ \\
\hline $\mathrm{A} 5$ & 85 & 10 & 5 & $\mathrm{C}_{1}$ & $\mathrm{~S}$ & $\mathrm{C}_{1}$ & $\mathrm{~S}$ & $\mathrm{C}_{1}$ & $\mathrm{~S}$ & $\mathrm{C}_{1}$ & $\mathrm{~S}$ \\
\hline $\mathrm{A} 6$ & 85 & 5 & 10 & $\mathrm{C}_{1}$ & $\mathrm{~S}$ & $\mathrm{C}_{1}$ & $\mathrm{~S}$ & $\mathrm{C}_{1}$ & $\mathrm{~S}$ & $\mathrm{C}_{1}$ & $\mathrm{~S}$ \\
\hline $\mathrm{A} 7$ & 80 & 15 & 5 & $\mathrm{C}_{1}$ & $\mathrm{~S}$ & $\mathrm{C}_{1}$ & $\mathrm{~S}$ & $\mathrm{C}_{1}$ & $\mathrm{~S}$ & $\mathrm{C}_{1}$ & $\mathrm{~S}$ \\
\hline $\mathrm{A} 8$ & 80 & 5 & 15 & $\mathrm{C}_{1}$ & $\mathrm{~S}$ & $\mathrm{C}_{1}$ & $\mathrm{~S}$ & $\mathrm{C}_{1}$ & $\mathrm{~S}$ & $\mathrm{C}_{1}$ & $\mathrm{~S}$ \\
\hline $\mathrm{A} 9$ & 80 & 10 & 10 & $\mathrm{C}_{1}$ & $\mathrm{~S}$ & $\mathrm{C}_{1}$ & $\mathrm{~S}$ & $\mathrm{C}_{1}$ & $\mathrm{~S}$ & $\mathrm{C}_{1}$ & $\mathrm{~S}$ \\
\hline
\end{tabular}

Legend:

$\begin{aligned} \mathrm{D} & =\text { Diesel } \\ \mathrm{B} & =\mathrm{CME} \\ \mathrm{E} & =\text { Ethanol } \\ \mathrm{S} & =\text { Stable }\end{aligned}$

any ratio. The blends using $100 \%$ ethanol purity were miscible at any ratio at room temperature (Kwanchareon et al., 2007). After six months storage, the blends of palm oil biodiesel, ethanol and diesel using $99.5 \%$ ethanol purity were miscible at room temperature with ethanol proportion of 5 to $15 \%$ (Cheenkachorn et al., 2006). A study using sunflower methyl ester as emulsifier for diesel-ethanol blends showed that addition of ethanol up to $12 \%$ at ambient temperature could make the blends stable. However, lower temperature and greater amount of ethanol added might lead to unstable blends (Rahimi et al., 2009).

\section{Engine Performance Testing}

In the engine performance testing, we tested the blends which showed high miscibility after long-term stability observation. They were $90 \%$ diesel-5\% ethanol-5\% CME (A3); 85\% diesel-5\% ethanol-10\% CME (A5, B5); $80 \%$ diesel-5\%

$\mathrm{C}_{1}=1$-phase clear liquid
$\mathrm{L}_{2}=2$-phase clear liquid
$\mathrm{T}_{2}=2$-phaseturbid
$\mathrm{U}=$ Unstable

ethanol-15\% CME (A7, B7) and 80\% diesel-10\% ethanol-10\% CME (A9, B9). These blends either contain $100 \%$ or $99.5 \%$ ethanol purity. In this test, idle or no load condition was applied to the engine.

Figure 1 shows the fuel rate consumption for diesel-ethanol-CME blends using $100 \%$ ethanol purity. As shown in the graph, A1 has the highest value and $A 5$ has the lowest value. The engine consumed the lesser amount of fuel at idle condition. It is because no load was put through the engine making the engine work at its minimum condition.

The fuel rate consumptions for the blends with $99.5 \%$ ethanol purity are shown in Figure 2. It shows that the fuel rate consumptions for the blends with 99.5\% ethanol purity were almost the same with the fuel rate consumption for the blends with $100 \%$ ethanol purity. In these blends, the more CME is added to the blend the higher the fuel rate consumption. 
6 Stability and Emission Characteristics of Diesel-Ethanol-Coconut Methyl Ester Blends for the Diesel Engines

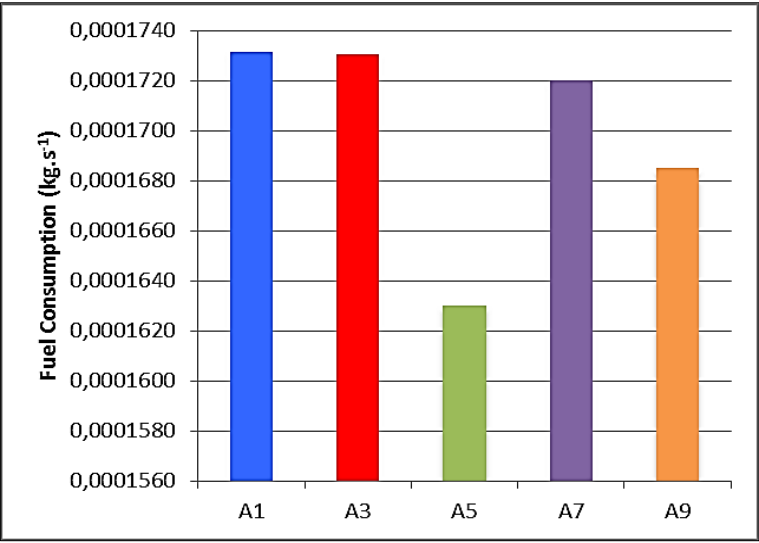

Fig.1: Fuel rate consumption for diesel-CMEethanol blends with $100 \%$ ethanol purity

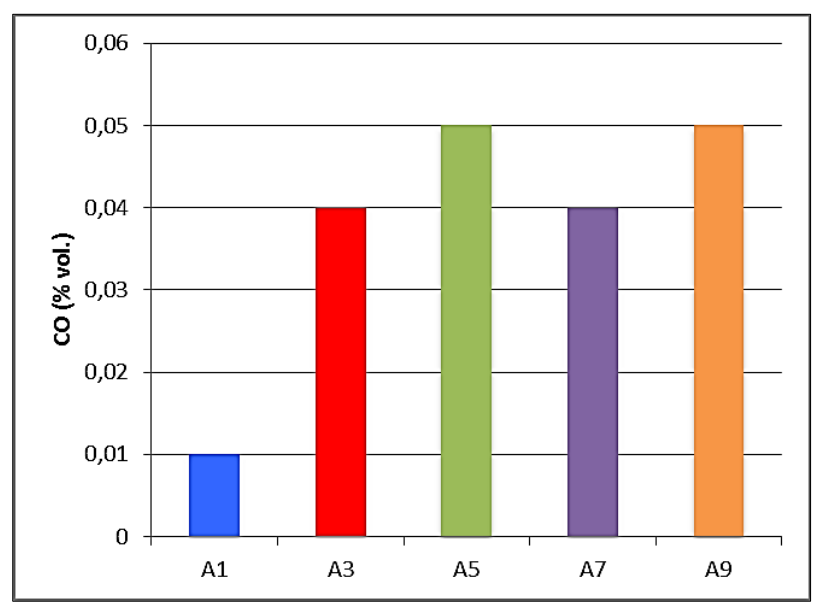

Fig.3: $\mathrm{CO}$ emissions for diesel-CME-ethanol blends with $100 \%$ ethanol purity

Engine operations at low speed especially at idle-no load and using a bigger size engine will lead to a minimum ignition delay and result in lower fuel rate consumption.

\section{Emission Testing}

Emission testing which include unburned hydrocarbon $(\mathrm{HC})$, carbon monoxide (CO), carbon dioxide $\left(\mathrm{CO}_{2}\right)$, unused oxygen $\left(\mathrm{O}_{2}\right)$ and nitrogen monoxide (NO) was conducted in this study.

The amount of $\mathrm{CO}$ and $\mathrm{HC}$ emissions of commercially available diesel (A1) were the lowest compared to the other fuel blends. Figure $\mathbf{4}$ and Figure $\mathbf{6}$,

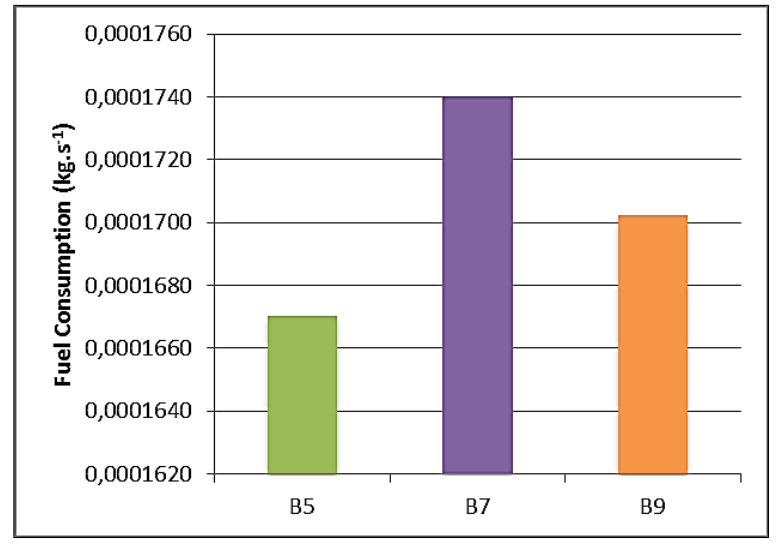

Fig.2: Fuel rate consumption for diesel-CMEethanol blends with $99.5 \%$ ethanol purity

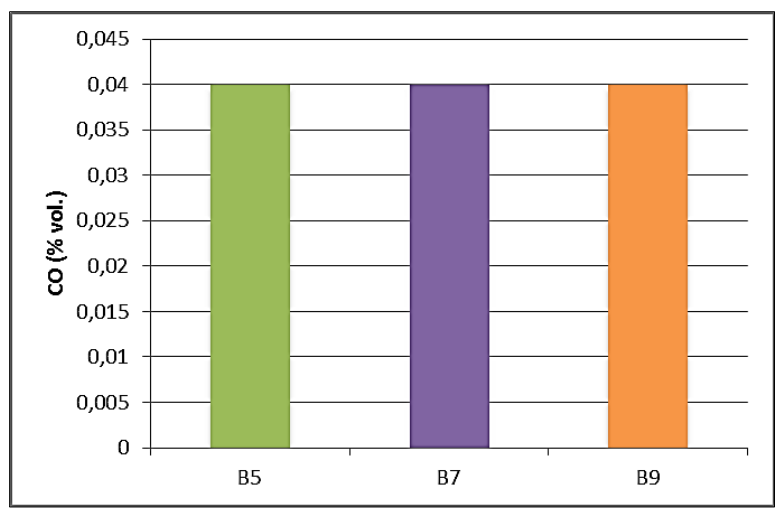

Fig.4: $\mathrm{CO}$ emissions for diesel-CME-ethanol blends with $99.5 \%$ ethanol purity

respectively, show the $\mathrm{CO}$ and $\mathrm{HC}$ emissions from the blends with 99.5\% ethanol purity, while $\mathrm{CO}$ and $\mathrm{HC}$ emissions from the blends with $100 \%$ ethanol purity are shown in Figure $\mathbf{3}$ and Figure $\mathbf{5}$, respectively. $\mathrm{CO}$ and $\mathrm{HC}$ emissions from the blends with $99.5 \%$ ethanol purity were lower than the emissions emitted from the blends with $100 \%$ ethanol purity.

The amount of $\mathrm{CO}$ and $\mathrm{HC}$ emissions were influenced by the amount of oxygen available in the combustion chamber. $\mathrm{HC}$ emissions have correlation with $\mathrm{CO}$, where the amount of $\mathrm{HC}$ will increase with increasing amount of $\mathrm{CO}$. The addition of ethanol (oxygenates) will result in the slight increase of $\mathrm{CO}$ emissions when 


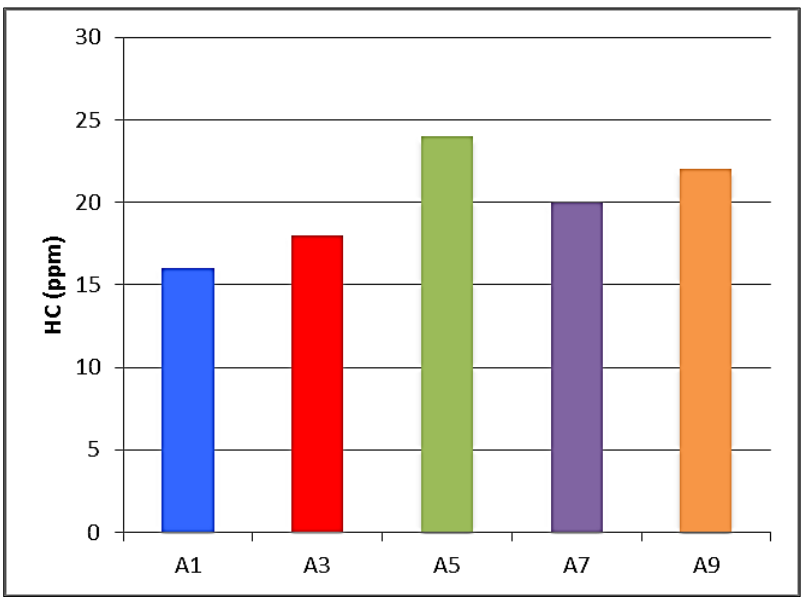

Fig.5: $\mathrm{HC}$ emissions for diesel-CME-ethanol blends with $100 \%$ ethanol purity

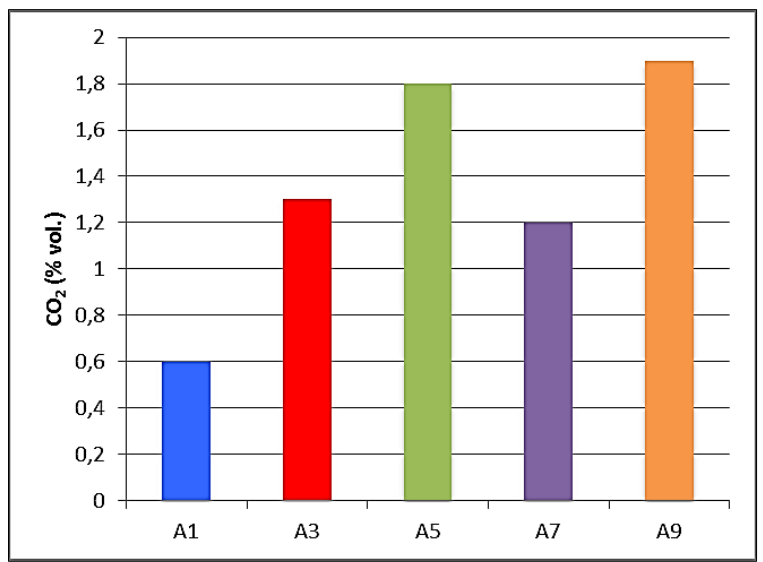

Fig.7: $\mathrm{CO}_{2}$ emissions for diesel-CME-ethanol blends with $100 \%$ ethanol purity

compared to the A1. This condition is due to the lower cetane number of ethanol which can cause the ignition delay and as a consequence will result to incomplete combustion of the fuel. The amount of $\mathrm{CO}$ formed also indicates that the oxygen available for the combustion was limited. The limited amount of oxygen in the combustion chamber resulted in the partial oxidation of the fuel which leads to the increasing amount of $\mathrm{CO}$ and $\mathrm{HC}$.

The $\mathrm{CO}_{2}$ emissions graphs in Figure 7 and Figure 8 for the blends with 100\% and $99.5 \%$ ethanol purity, respectively, also have the same trend with the $\mathrm{CO}$ and $\mathrm{HC}$ emissions. Yet it must be understood that

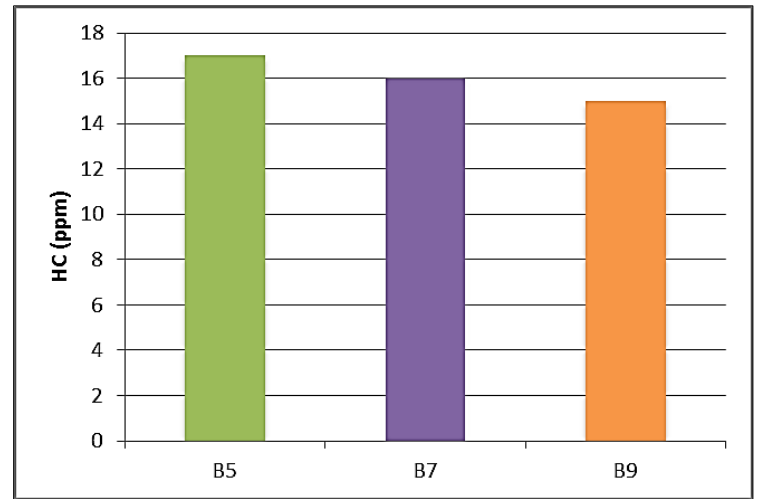

Fig.6: $\mathrm{HC}$ emissions for diesel-CME-ethanol blends with $100 \%$ ethanol purity

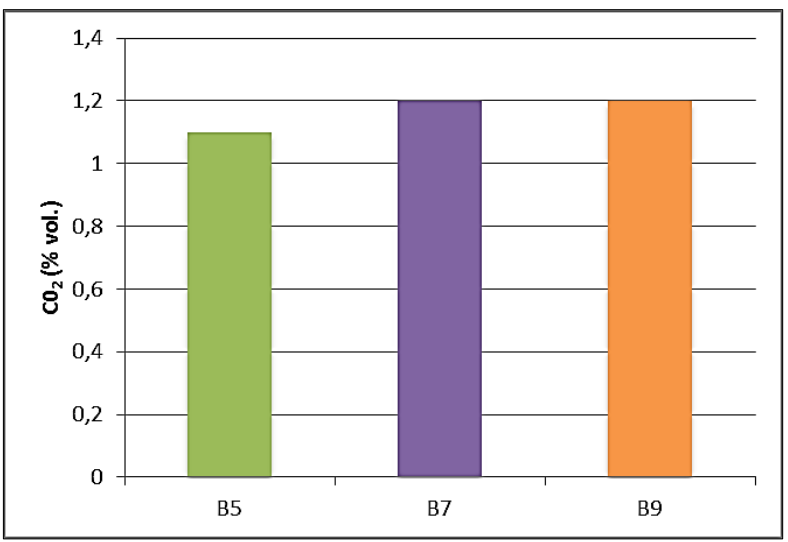

Fig.8: $\mathrm{CO}_{2}$ emissions for diesel-CME-ethanol blends with $99.5 \%$ ethanol purity

the amount of $\mathrm{CO}_{2}$ emitted from the engine were higher than $\mathrm{CO}$. In this test, the engine runs efficiently since the amount of $\mathrm{CO}_{2}$ is higher than $\mathrm{CO} . \mathrm{CO}_{2}$ emissions for the new-blended fuels were higher during the combustion compared to $A 1$ due to the addition of CME. This is because more sufficient amount of oxygen is present in the combustion chamber when fueled with $A 1$. It is also known that an efficient combustion will produce higher $\mathrm{CO}_{2}$ emissions than $\mathrm{CO}$ on account of sufficient amount of oxygen in the combustion chamber obtained from the oxygenates, $\mathrm{CME}$ and ethanol. $\mathrm{CO}_{2}$ emission is also related to the $\mathrm{NOx}$ 
8 Stability and Emission Characteristics of Diesel-Ethanol-Coconut Methyl Ester Blends for the Diesel Engines

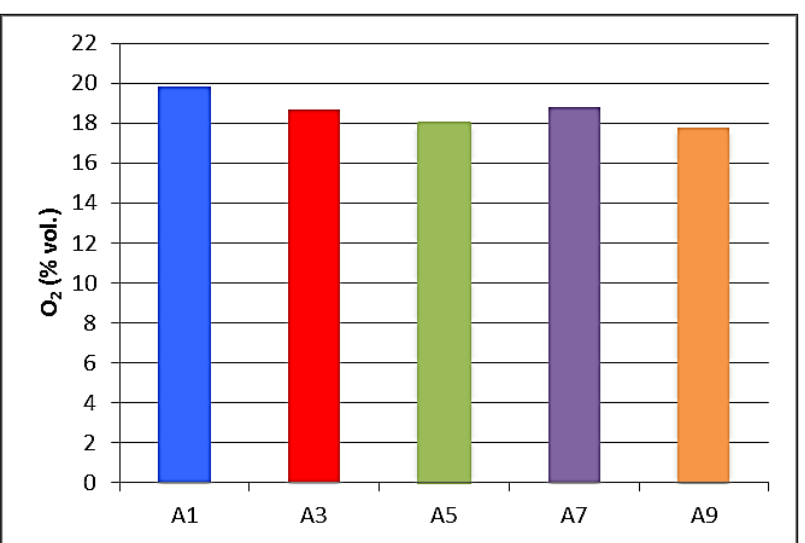

Fig.9: $\mathrm{O}_{2}$ emissions for diesel-CME-ethanol blends with $100 \%$ ethanol purity

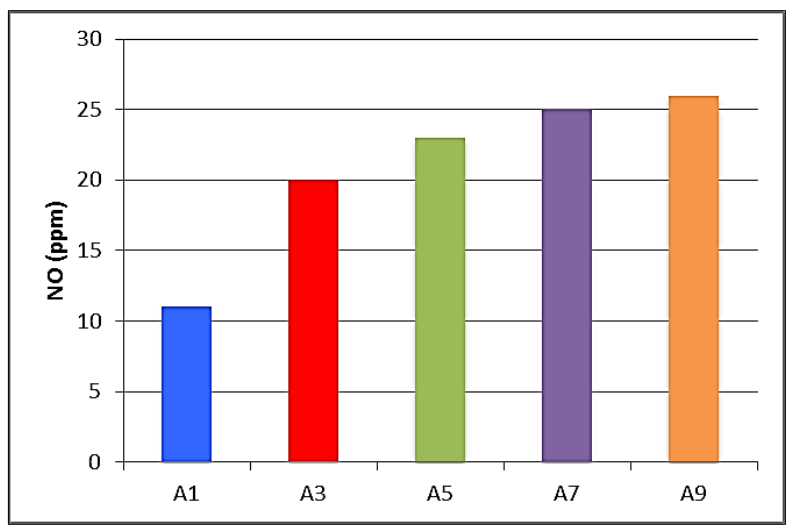

Fig.11: NO emissions for diesel-CME-ethanol blends with $100 \%$ ethanol purity

emission where an increase in $\mathrm{CO}_{2}$ is also an indication that NOx is increased.

As compared in Figure 9 and Figure 10, the highest concentration of unused $\mathrm{O}_{2}$ was from $\mathrm{A} 1$. The $\mathrm{O}_{2}$ emissions will go higher with decreasing speed. In contrast, the emissions of new-blended fuels will go lower with the decreasing speed. The \% by volume of unused $\mathrm{O}_{2}$ were the highest amongst other emission gases.

The NO emissions emitted from the engine were very minimal. A1 had the lowest $\mathrm{NO}$ emissions compared to other fuels as shown in Figure $\mathbf{1 1}$ and Figure 12. The NO amounts were correlated with the $\mathrm{CO}_{2}$ emissions where the increasing amount of $\mathrm{CO}_{2}$ will initiate the increasing

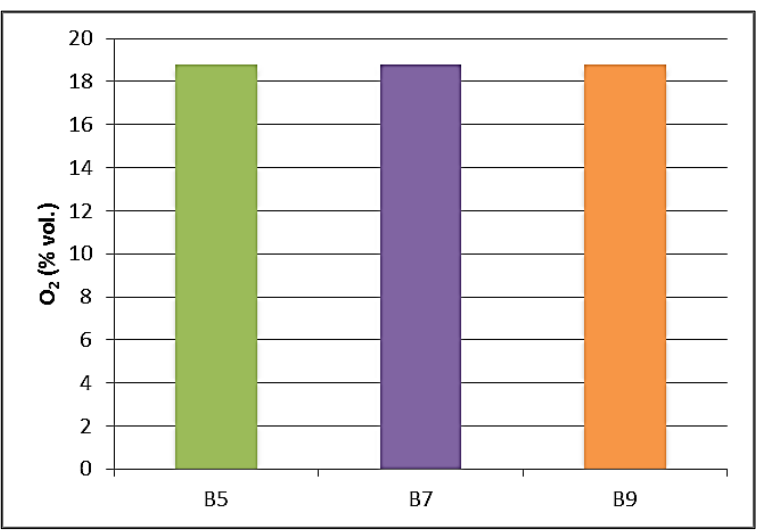

Fig. 10: $\mathrm{O}_{2}$ emissions for diesel-CME-ethanol blends with $100 \%$ ethanol purity

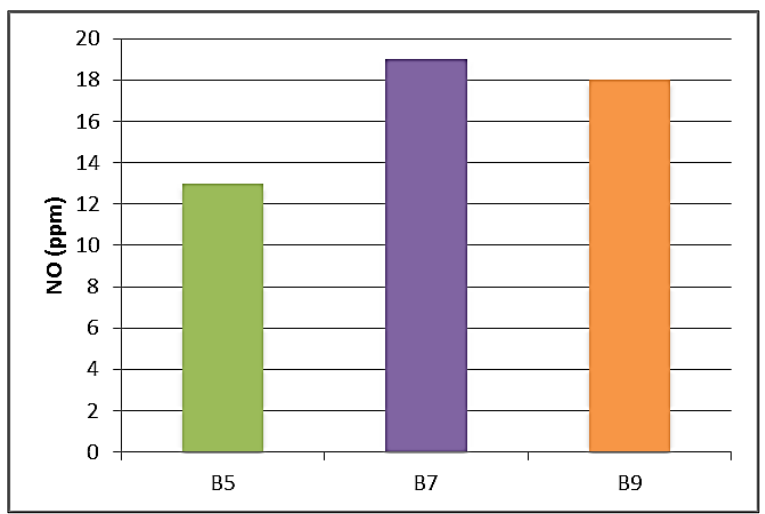

Fig.12: NO emissions for diesel-CME-ethanol blends with $99.5 \%$ ethanol purity

amount of NO.

The diesel-CME-ethanol blends using $99.5 \%$ and $100 \%$ ethanol purity showed that the unused $\mathrm{O}_{2}$ are the highest compared to others and the $\mathrm{CO}$ emissions are the lowest compared to $\mathrm{CO}_{2}$ and $\mathrm{O}_{2}$. This observation showed that the diesel engine fueled with new-blended fuels could run efficiently. Our results of the exhaust emission tests at no load condition conformed to the previous studies in emission testing at no load condition using rice bran oil biodiesel (Subbaiah et al., 2010; Singh et al., 2007); waste cooking oil (Yilmaz, 2012); and palm oil biodiesel (Kwanchareon et al., 2007).

This study also measured the smoke 


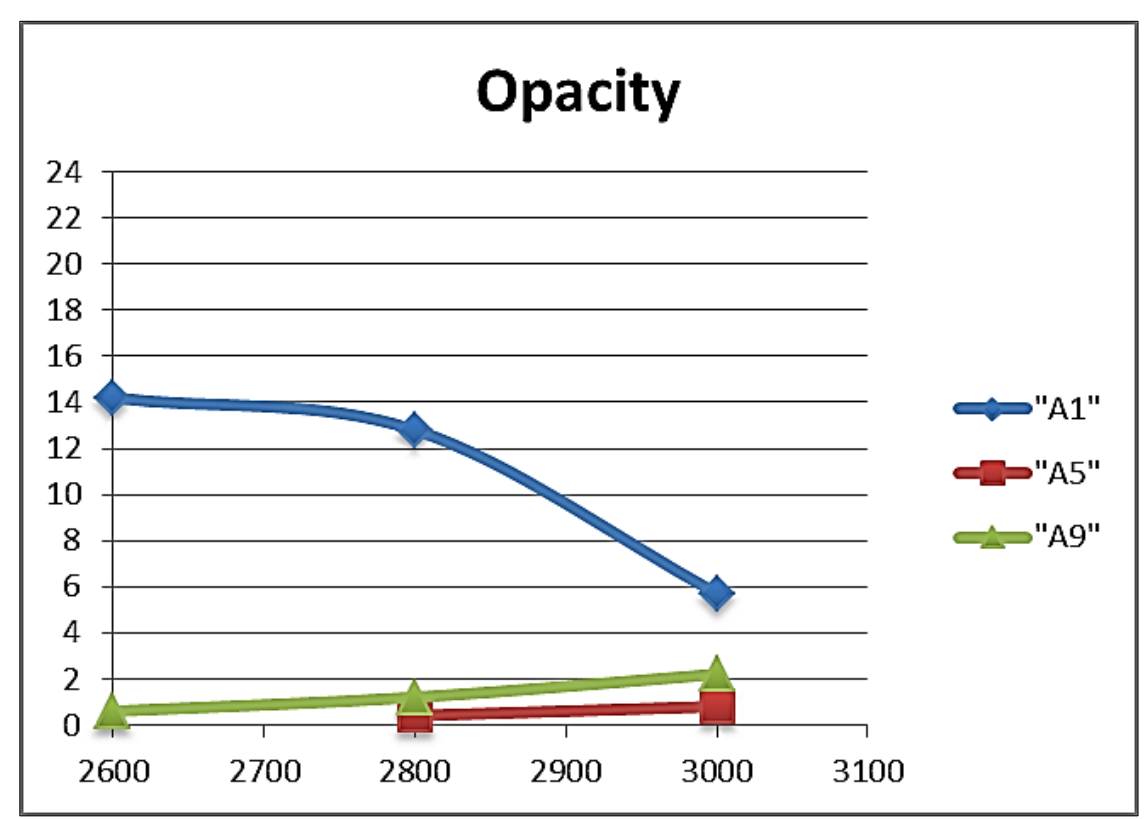

Fig.13: Opacity for diesel-CME-ethanol blends

opacity for A1, A7 and A9 with load condition. The opacity results from the gaseous emission showed that the opacity of $A 1$ were higher than the blends of $A 5$ and A9. Figure 13 shows that the opacity of $A 1$ increased with the decreasing speed and decreased after reaching its maximum while the opacity of $A 5$ and $A 9$ were decreasing with the decreasing speed and had values that are not much different.

The smoke opacity is always expressed by a $\mathrm{K}$-value. A larger $\mathrm{K}$ value indicates a higher amount of the smoke opacity. The addition of CME can decrease the smoke opacity compared to diesel. It is due to the more complete and stable combustion of the fuel than $A 1$, since the fuel contains more oxygen from ethanol. The more stable combustion of the engine fueled with new blended fuel was influenced by the lower ignition delay of the engine compared to the engine fueled with $\mathrm{A} 1$. Smoke opacity indicates the black smoke emission exhausted by the engine that consists of particulate matter (PM) smaller than 10 microns. It means that the decreasing amount of the smoke opacity indicates that the amount of PM is reduced.

\section{CONCLUSSIONS}

The stability and emission characteristics of diesel-ethanol-CME blends in various proportions of the components were investigated in order to assess the potential of the fuel as a substitute for commercially available diesel fuel used in diesel engine.

The diesel-CME-ethanol blends with 99.5\% ethanol purity and $0.5 \%$ water content in the solutions, exhibited two stability behaviors: miscible liquid and immiscible liquid. All of the blends at this ethanol concentration were stable at $40^{\circ} \mathrm{C}$. High mutual solubility at any temperature ranges were attained by the dieselethanol-CME blends with $100 \%$ ethanol 
10 Stability and Emission Characteristics of Diesel-Ethanol-Coconut Methyl Ester Blends for the Diesel Engines

purity. The fuel blends with no water present in ethanol were stable at temperatures greater than $25^{\circ} \mathrm{C}$ at any proportions of the blends.

The fuel blends using 100\% and 99.5\% ethanol purity with ethanol proportion of up to $10 \%$ and CME of $5 \%$ and greater exhibited high mutual solubility at any temperature range. The diesel-CMEethanol blends were resistant to microbial growths for all the stable samples after three months storage.

The diesel-ethanol-CME blends at proportion of $90 \%$ diesel, $5 \%$ ethanol, and $5 \%$ CME; $85 \%$ diesel, $5 \%$ ethanol, and $10 \%$ CME; $80 \%$ diesel, 5\% ethanol, and 15\% $\mathrm{CME}_{\text {; }}$ and $80 \%$ diesel, 10\% ethanol, and $10 \%$ CME using $100 \%$ and $99.5 \%$ ethanol purity were subjected to engine performance and emission testing because of their homogeneity and stability after a long-term storage.

The size of the engine and operation at low speed especially at idle-no load condition affected the fuel rate consumption of the engine. At low speed and using a bigger size engine, the ignition delay is minimal and will result in the lower fuel rate consumption. The use of the new-blended fuels in diesel engine could deliver an efficient combustion and could run efficiently since the production of $\mathrm{CO}_{2}$ gases are higher than $\mathrm{CO}$. The emission testing results showed a reduction of $\mathrm{CO}_{2}$ and smoke opacity and increasing percentage by volume of $\mathrm{CO}$ of the blends compared to $A 1$. The blends of 85D10B5E and 80D10B10E could reduce the smoke opacity or particulate matter emissions compared to $\mathrm{A} 1$.

\section{ACKNOWLEDGEMENTS}

The authors would like to express their gratitude for the contributions and support of AUN/SEED-net and JICA, Chemical Engineering Department of De La Salle University, Gadjah Mada University and Tokyo Institute of Technology.

\section{REFERENCES}

1. Alleman, T.L. McCormick, R.L.; "Analysis of Coconut-Derived Biodiesel and Conventional Diesel Fuel Samples from the Philippines: Task 2. Final Report", National Renewable Energy Laboratory. Colorado (2006).

2. Cheenkachorn, K. Narasingha, M. H. Papakornnopaut, J.; "Biodisel as an Additive for Diesohol", Asian journal on Energy and Environment, Vol. 7, No.01, pp. 267 -276 (2006)

3. De Caro, P. S. Moulongui, Z. Vaitilingom, G. Berge J.Ch.; "Interest of Combining an Additive with DieselEthanol Blends for Use in Diesel Engines", Fuel, Vol. 80, pp. 565-574 (2001)

4. Fernando, S., Hanna, M.; "Development of a Noval Biofuel Blend Using EthanolBiodiesel-Diesel Microemulsions: EBDiesel," Energy Fuel, Vol. 18, pp. 16851703 (2004)

5. Kim, H. Choi, B.; "The Effect of Biodiesel and Bioethanol Blended Diesel Fuel on Nanoparticles and Exhaust Emissions from CRDI Diesel Engine", Renewable energy, Vol. 35, pp. 157-163 (2010)

6. Kwanchareon, P. Luengnaruemitchai, A. Jai-In, S.; "Solubility of a DieselBiodiesel-Ethanol Blend, Its Fuel 
Properties, and Its Emission

Characteristics from Diesel Engine", Fuel, Vol. 86, pp. 1053 - 1061 (2007)

7. Pang, X. Shi, X. Mu, Y. He, H. Shuai, S. Chen, H. Li, R.; "Characteristics of Carbonyl Compounds From a Diesel Engine Using Biodiesel-Ethanol-Diesel as Fuel", Atmospheric Environment, Vol. 40, pp. 7057-7065 (2006)

8. Qi, D. H., Chen, H., Geng, L. M., Bian, Y. Z.; "Effect of Diethyl Ether and Ethanol Additives on The Combustion and Emission Characteristics of BiodieselDiesel Blended Fuel Engine", Renewable Energy, Vol. 36, pp. 1252-1258 (2011)

9. Rahimi, H. Ghobadian, B. Yusaf, T. Najafi, G. Khatamifar, M.; "Diesterol: An Environment-Friendly IC Engine Fuel", Renewable Energy, Vol. 34, pp. 335-342 (2009)

10. Randazzo, M. L., Sodré, J. R.; "Cold Start and Fuel Consumption of a Vehicle Fuelled with Blends of Diesel OilSoybean Biodiesel-Ethanol", Fuel, Vol. 90, pp. 3291-3294 (2011)

11. Singh, J. Mishra, T. N. Bhattacharya, T. K. Singh, M. P.;

"Emission
Characteristics of Methyl Ester of Rice Bran Oil as Fuel in Compression Ignition Engine", World Academy of Science, Engineering and Technology, Vol. 3, No.6, pp. 198-202 (2007)

12. Subbaiah, G. V. Gopal, K. R. Hussain, S. A. Prasad, B. D. K. Reddy, K. T.; "Rice Bran Oil as an Additive for DieselEthanol Blends for Diesel Engines", International Journal of Research and Reviews in Applied Sciences, Vol. 3, No. 3, pp. 334-342 (2010)

13. Venkanna, B.K. Venkataramana, C. Reddy. Swati, B. Wadawadagi.; "Performance, Emission and Combustion Characteristics of Direct Injection Diesel Engine Running on Rice Bran Oil/ Diesel Fuel Blend", International Journal of Chemical and Biomolecular Engineering, Vol. 2, No. 3, pp. 131-137 (2009)

14. Yilmaz, N.; "Comparative Analysis of Biodiesel-Ethanol-Diesel and BiodieselMethanol-Diesel Blends in a Diesel Engine", Energy, Vol. 40, pp. 210-213 (2012) 